\title{
Career Development of Upper Elementary Students through STEAMS-Based Gardening Programs
}

\author{
Jeungeun Jang ${ }^{1}$, Jong Won Hong ${ }^{2}$, and Jongyun Kim ${ }^{3 *}$ \\ ${ }^{1}$ Masters student, Department of Horticulture and Biotechnology, Korea University, Seoul, 02841, Korea \\ ${ }^{2}$ Research professor, Institute of Life Science and Natural Resources, Korea University, Seoul, 02841, Korea \\ ${ }^{3}$ Associate professor, Division of Biotechnology, Korea University, Seoul, 02841, Korea
}

\section{ABSTRACT}

Since elementary school is a time in which basic concepts like attitudes and mindsets about careers are formed, career education is very important to elementary school students. This study was conducted to investigate the effects of a gardening program applying the academic disciplines of Science, Technology, Engineering, Arts, Mathematics, and Society (STEAMS) on developing career education for elementary school students. In order to determine the effectiveness of the program on career development of elementary school students, this study was conducted with 28 upper elementary students in the experimental group who participated in the gardening program, and 30 upper elementary students in the control group who did not. The program was comprised of total 8 sessions, one session per week, with various garden activities. The career development scores of the two groups before and after the program were comparatively analyzed. Before the program, the experimental group had significantly lower scores for career development than the control group. After 8 weeks of the program, the control group did not show any changes in career development, while the experimental group that participated in the program showed a significant increase in career development, resulting in no difference in career development between the two groups after the program. Therefore, the program has positive effects on improving career development of upper elementary students who previously had insufficient career development. Overall, the program had positive effects on career development of upper elementary students, and further research is needed to systematically promote the STEAMS-based gardening program to promote interest and understanding of students by associating plant-based gardening activities with various subjects such as science, art, and social studies.

Keywords: children vocational development, horticultural activity, horticultural education, school gardening STEAM program

\section{Introduction}

Currently, the Korean society is undergoing various changes due to the development of science and technology. In the World Economic Forum Annual Meeting 2016 in Davos, Switzerland, Executive Chairman Klaus Schwab announced that the contemporary society is facing the Fourth Industrial Revolution, and predicted that intelligent information technology such as artificial intelligence, Internet of Things (IoT), cloud, big data and mobile will generate occupations in new, specialized fields in con- vergence with the society (Schwab, 2016).

According to the Elementary and Middle School Career Education Survey 2018 announced by the Ministry of Education and Korea Research Institute for Vocational Education and Training, elementary school period is the time in which the ratio of students with desired occupations is the highest. The most common reason for choosing their desired occupations was because 'I like to do it', followed by 'I can do it well' and 'I can come up with ideas and work creatively'. These results show that elementary school is when students are enthusiastic to work creatively, and

Received: December 10, 2019, Revised: February 24, 2020, Accepted: March 16, 2020

First author: Jeungeun Jang, florist.grace@gmail.com, (1) https://orcid.org/0000-0001-7353-7042

*Corresponding author: Jongyun Kim, jongkim@korea.ac.kr, (D) https://orcid.org/0000-0001-8085-9592 
thus there is a need for systematic career education programs to develop creativity in preparing for the changing future society (Jeung et al., 2018).

Elementary school is the time in which students form the basic concepts and attitudes as well as mindsets about careers (Hartung et al., 2005), and begin to perceive and explore careers and show vocational preference (Super et al., 1996). Students begin to show massive interest in their career already in Grades 3 and 4 of elementary school, and by Grade 6, at least half of them potentially choose their career (Seo and Do, 2002), which implies that this is an important time that lays the groundwork for career education (Lee and Chung, 2014). Jyung et al. (2012) emphasized the need to support diverse and extensive career activities during the years of elementary school

The Ministry of Education decided that the existing elementary and middle school system is limited in terms of developing creative talent, and thus intended to cultivate Science, Technology, Engineering, Arts, Mathematics (STEAM) talent that can creatively and comprehensively solve problems by proposing STEAM education in 2011 (Ministry of Education, 2010). STEAM is an integrated curriculum of Science, Technology, Engineering, Arts and Mathematics, which promotes interest and understanding about science and technology, and improve STEAM literacy and real-world problem-solving skills (Korea Foundation for the Advancement of Science and Creativity, 2011). Accordingly, based on the Gyeonggi Education Basic Plan and Gyeonggi Ordinance on the Promotion and Support of Gyeonggi Village Education Community (No. 5078), Gyeonggi founded Gyeonggi Dream School to build an educational ecosystem based on collaboration of school and community so that students can design their own dreams, explore their ego and career through experience, and grow into a well-rounded person with a harmony of personality, intelligence and sensibility (Gyeonggido Office of Education, 2014). Dream School is a school that fulfills the dreams of students by enabling them to explore careers based on free humanistic imagination with the collaboration of school and community and to participate in various cultural, art and sports activities (Gyeonggido Office of Education, 2015).

Recently, gardening education is actively implemented worldwide for nature-friendly education. The Royal Horticultural Society (RHS) in the UK encourages school gardening by holding the RHS Campaign for School Gardening (Royal Horticultural Society [RHS], 2018). School gardening not only promotes physical health with motions such as digging (Cameron, 2016), but also allows students to enjoy a healthier diet with increased attempts to consume new fruits or vegetables (Passy et al., 2010). Pursuing the shared goal of cultivating plants also has positive effects on social interactions of students, which increases confidence and helps them build relationships and fulfill social growth. Moreover, gardening activities also provide new extensive knowledge in literature, science and arts (Cameron, 2016), providing the educational effect of improving focus by giving students the will to learn and actively approach problem solving (RHS, 2010). According to RHS (2018), school gardening is a perfect curriculum of convergence that increases nature-related happiness for students by giving them a great sense of achievement and responsibility.

Since STEAM education first appeared in Korea, studies and teaching methods focusing on mathematics and science have been presented, but there is a severe lack of studies on horticulture or gardens among the countless studies on STEAM in Korea. Therefore, this study examined the effects of a STEAMS-based program comprised of gardening activities on career development of elementary school students and determined student assessment on the program.

\section{Research Methods}

\section{Participants and period}

This study was conducted to determine the effects of 'Eco Garden Design' STEAMS-based gardening program, carried out as part of the 'Gyeonggi Dream School' project hosted by Gyeonggi Provincial Office of Education and Village Education Community, on career development of elementary school students. There were total 58 participants, 28 in the experimental group that participated in the gardening program and 30 in the control group that did not participate in the 'Gyeonggi Dream School' program. The experimental group consisted of upper elementary stu- 
dents in Seongnam and Yongin who voluntarily applied for participation, with the consent of their guardians, in the 'Gyeonggi Dream School-Eco Garden Design' program in 2019. For demographic homogeneity with the experimental group, the control group consisted of upper-grade students in three elementary schools where the biggest number of participants attend, who do not participate in the 'Gyeonggi Dream School' program but wish to participate in this study. The control group was formed with students willing to participate upon receiving the consent of legal representatives through a newsletter explaining the purpose of research and guidance. The program, comprised of total 8 sessions (once a week, 180 minutes per session), was carried out from May to July 2019 by two horticulturists for welfare and three assistants at the outdoor garden and in the classroom of S Elementary School in Seohyeon-dong, Bundang-gu, Seongnam in Gyeonggi.

\section{Tools}

This study used the career development test for elementary school students developed by Lee (2005) to measure the change in career development of elementary school students. The career development test is comprised of total 41 items in three categories: self-awareness (awareness of self-concept, awareness of self-trait, awareness of human relations), education and occupational exploration (awareness of relationship between career and learning, awareness of relationship among work, personal responsibility and society function, understanding and use of the career information), and career planning (understanding the decision-making process, understanding the interrelationship of life roles, understanding career planning process; Table 1). The items were rated on a 5-point Likert scale, and as a result of analyzing reliability of each item, Cronbach's $\alpha$ by Lee (2005) was .936 , and Cronbach's $\alpha$ of this study was .942 , verifying the reliability of the questionnaire.

\section{Gardening program design}

The gardening program used in this study is a direct/indirect experience-based career program for middle school students called 'From Seed to Flower cafe', which is a STEAMS-based gardening program developed by the

Table 1. Reliability of the questionnaires for career development test for elementary school students

\begin{tabular}{|c|c|c|c|c|}
\hline \multicolumn{2}{|c|}{ Category (Number of questionnaires) } & Content & $\begin{array}{c}\text { Cronbach's } \\
\alpha \text { from Lee } \\
(2005)^{\mathrm{z}}\end{array}$ & $\begin{array}{c}\text { Cronbach's } \\
\alpha \text { of this } \\
\text { study }\end{array}$ \\
\hline \multirow{3}{*}{$\begin{array}{l}\text { Self-awareness } \\
\qquad(10)\end{array}$} & Awareness of self-concept (3) & Awareness to which you think positively about yourself & \multirow{3}{*}{.98} & \multirow{3}{*}{.839} \\
\hline & Awareness of self-trait (4) & Understanding of one's strengths and characteristics & & \\
\hline & Awareness of human relations ( 3 ) & Awareness of positive and effective interaction with others & & \\
\hline \multirow{3}{*}{$\begin{array}{l}\text { Education and } \\
\text { occupational } \\
\text { exploration } \\
\text { (13) }\end{array}$} & $\begin{array}{l}\text { Awareness of the relationship } \\
\text { between career and learning (2) }\end{array}$ & $\begin{array}{l}\text { Degree of recognition of the importance of learning in } \\
\text { choosing a career }\end{array}$ & \multirow{3}{*}{.844} & \multirow{3}{*}{.832} \\
\hline & $\begin{array}{l}\text { Awareness of the relationship } \\
\text { among work, personal } \\
\text { responsibility and society } \\
\text { function (3) }\end{array}$ & Understanding the meaning of work in one's environment & & \\
\hline & $\begin{array}{l}\text { Understanding and use of the } \\
\text { career information ( } 8 \text { ) }\end{array}$ & $\begin{array}{l}\text { Degree of active exploration and utilization of career } \\
\text { related information }\end{array}$ & & \\
\hline \multirow{3}{*}{$\begin{array}{c}\text { Career } \\
\text { planning } \\
(18)\end{array}$} & $\begin{array}{l}\text { Understanding the } \\
\text { decision-making process ( } 3 \text { ) }\end{array}$ & Understanding of the rational decision-making process & \multirow{3}{*}{.911} & \multirow{3}{*}{.928} \\
\hline & $\begin{array}{l}\text { Understanding the } \\
\text { interrelationship of life roles (5) }\end{array}$ & Degree of planned behavior in a given life role & & \\
\hline & $\begin{array}{l}\text { Understanding career planning } \\
\text { process }(10)\end{array}$ & Recognition and understanding of future career plans & & \\
\hline \multicolumn{3}{|l|}{ Total (41) } & .936 & .942 \\
\hline
\end{tabular}


Table 2. Gardening activity programs based on the academic discipline of STEAMS

\begin{tabular}{|c|c|c|c|c|}
\hline \multirow{2}{*}{ Session } & \multirow{2}{*}{ Field } & \multicolumn{2}{|l|}{ Direct experience } & \multirow{2}{*}{$\begin{array}{c}\text { Indirect experience } \\
\text { Introducing occupation }\end{array}$} \\
\hline & & Gardening activity & Creative activity & \\
\hline 1 & $\begin{array}{c}\text { Flower } \\
\text { decoration }\end{array}$ & Arranging a centerpiece with fresh cut flowers & $\begin{array}{c}\text { Flower } \\
\text { decoration }\end{array}$ & Florist \\
\hline 2 & $\begin{array}{c}\text { Plant } \\
\text { cultivation }\end{array}$ & $\begin{array}{l}\text { Designing a school garden and planting seeds, herbs and } \\
\text { seasonal flowers in the school garden }\end{array}$ & Garden design & Gardener \\
\hline 3 & $\begin{array}{l}\text { Plant } \\
\text { cultivation }\end{array}$ & Repotting indoor plants & Pot design & Indoor landscape designer \\
\hline 4 & $\begin{array}{c}\text { Plant } \\
\text { propagation }\end{array}$ & $\begin{array}{l}\text { Planting wheat grass (Triticum aestivum L.) in the soil and } \\
\text { water culture }\end{array}$ & $\begin{array}{l}\text { Seed inspection } \\
\text { and sorting }\end{array}$ & Seed quality manager \\
\hline 5 & $\begin{array}{l}\text { Post-harvest } \\
\text { using }\end{array}$ & $\begin{array}{l}\text { Making bug spray and soaps from the herbs in the school } \\
\text { garden }\end{array}$ & $\begin{array}{l}\text { Combine } \\
\text { fragrance }\end{array}$ & Aroma therapist \\
\hline 6 & $\begin{array}{c}\text { Plant } \\
\text { propagation }\end{array}$ & Making pots with clay and planting succulents & $\begin{array}{l}\text { Planting and } \\
\text { acting empathy }\end{array}$ & Horticultural therapist \\
\hline 7 & $\begin{array}{c}\text { Flower } \\
\text { decoration }\end{array}$ & Making pressed flowers and writing dreams on the fan & $\begin{array}{l}\text { Pressed flower } \\
\text { making }\end{array}$ & $\begin{array}{c}\text { Floral product processing } \\
\text { designer }\end{array}$ \\
\hline 8 & $\begin{array}{l}\text { Post-harvest } \\
\text { using }\end{array}$ & $\begin{array}{l}\text { Having a garden party with plants in the school garden that } \\
\text { we grew }\end{array}$ & Cooking & Garden party planner \\
\hline
\end{tabular}

Note. STEAMS = science, technology, engineering, art, mathematics and society.

National Institute of Horticultural and Herbal Science of Rural Development Administration. We adjusted the difficulty of this program to be suitable for the development stages of elementary school students, and organized it so that gardening and creative activities can be aligned with career by categorizing the program into plant cultivation, plant propagation, post-harvest use, and flower decoration (Table 2). The 'From Seed to Flower Cafe' program includes creative design to provide problem solving situations and solutions according to the STEAM framework and emotional touch through problem solving. Moreover, it is a program developed by adding Society (sociality) to STEAM elements such as Science (nature-related theories), Technology (technology using science), Engineering (system in convergence with technology), Arts (artistic sensibility), and Mathematics (arithmetic, math, mathematical principles), as well as elements required to have occupations such as knowledge, intellectual capacity and personality (Jeung et al., 2017).

\section{Data analysis}

To determine the effects of STEAMS-based gardening activities on career development of elementary school stu- dents, this study verified the possibility of parametric test $(p>.05)$ using Levene's test on the experimental group that participated in the program and the control group that did not. An independent samples t-test was conducted to compare the two groups, and the pretest-posttest differences were comparatively analyzed using the paired sample t-test of each group. This study used the SPSS WIN 12.0 (IBM Co., Armonk, NY, USA) program for statistical analysis of collected data, and the significance level was set as $p<.05$.

\section{Results and Discussion}

The results of examining the effects of the STEAMS-based gardening program on career development are as follows.

\section{Demographic characteristics}

The elementary school students who participated in this study were 20 male students (34.5\%) and 38 female students $(65.5 \%)$. Thirty seven $(63.8 \%)$ were in Grade 4 , one $(1.7 \%)$ in Grade 5, and 20 (34.5\%) in Grade 6, and 40 students (69\%) lived in Seongnam and $18(31 \%)$ lived in 
Table 3. Demographic characteristics of the participants and homogeneity test between the control and the experimental groups

\begin{tabular}{|c|c|c|c|c|c|c|}
\hline \multirow{2}{*}{\multicolumn{2}{|c|}{ Characteristic }} & \multicolumn{3}{|c|}{ Frequency (n) } & \multirow{2}{*}{ Percent (\%) } & \multirow{2}{*}{$p$} \\
\hline & & Control & Experimental & Total & & \\
\hline \multirow{2}{*}{ Gender } & Male & 12 & 8 & 20 & 34.5 & \multirow{2}{*}{$.369^{\mathrm{Ns}}$} \\
\hline & Female & 18 & 20 & 38 & 65.5 & \\
\hline \multirow{3}{*}{ Grade } & 4 th & 17 & 20 & 37 & 63.8 & \multirow{3}{*}{$.19^{\mathrm{NS}}$} \\
\hline & 5 th & 0 & 1 & 1 & 1.7 & \\
\hline & 6 th & 13 & 7 & 20 & 34.5 & \\
\hline \multirow{2}{*}{ City } & Seongnam & 20 & 20 & 40 & 69.0 & \multirow{2}{*}{$.70^{\mathrm{NS}}$} \\
\hline & Yongin & 10 & 8 & 18 & 31.0 & \\
\hline
\end{tabular}

Note. $\mathrm{N}=58$.

${ }^{\mathrm{NS}}$ Non-significant by independent t-test.

Table 4. Pre-GAP and Post-GAP differences and homogeneity test in the total score between the control and the experimental groups

\begin{tabular}{|c|c|c|c|c|c|}
\hline \multirow{2}{*}{ Category } & \multirow{2}{*}{ Group } & \multicolumn{2}{|c|}{ Mean (SD) } & \multirow{2}{*}{$t$} & \multirow{2}{*}{$p$} \\
\hline & & Pre-GAP & Post-GAP & & \\
\hline \multirow{3}{*}{ Self-awareness } & Control & $41.83(4.89)$ & $41.10(6.69)$ & 0.90 & $.372^{\mathrm{NS}}$ \\
\hline & Experimental & $39.14(6.72)$ & $42.43(5.46)$ & -3.51 & $.002^{* *}$ \\
\hline & $p$ & $.085^{\mathrm{NS}}$ & $.413^{\mathrm{NS}}$ & & \\
\hline \multirow{3}{*}{ Education and career exploration } & Control & $46.57(8.68)$ & $48.07(7.18)$ & -1.23 & $.225^{\mathrm{NS}}$ \\
\hline & Experimental & $38.79(6.59)$ & $47.79(6.74)$ & -7.68 & $<.001^{* * *}$ \\
\hline & $p$ & $<.001^{\dagger+\dagger}$ & $.879^{\mathrm{NS}}$ & & \\
\hline \multirow{3}{*}{ Career planning } & Control & $65.90(14.01)$ & $66.23(12.78)$ & -0.29 & $.774^{\mathrm{NS}}$ \\
\hline & Experimental & $54.64(11.83)$ & $65.71(10.51)$ & -7.36 & $<.001^{* * *}$ \\
\hline & $p$ & $.002^{\dagger \dagger}$ & $.867^{\mathrm{NS}}$ & & \\
\hline \multirow{3}{*}{ Total } & Control & $154.30(24.46)$ & $155.40(22.74)$ & -0.52 & $.602^{\mathrm{NS}}$ \\
\hline & Experimental & $132.57(20.48)$ & $155.93(20.73)$ & -8.13 & $<.001^{* * *}$ \\
\hline & $p$ & $<.001^{\dagger \dagger}$ & $.927^{\mathrm{NS}}$ & & \\
\hline
\end{tabular}

Note. GAP $=$ gardening activity program.

${ }^{\mathrm{NS}}$ Non-significant, ${ }^{* *} p<.01,{ }^{* * *} p<.001$ by paired t-test.

${ }^{\mathrm{NS}}$ Non-significant, ${ }^{\dagger} p<.01,{ }^{\dagger \dagger} p<.001$ by independent t-test.

Yongin. The demographic characteristics of the participants in this study are as shown in Table 3. The demographic characteristics of the two groups were homogenous in terms of gender, grade and city before the program. However, in the preliminary test of homogeneity on the career development test (self-awareness, education and occupational exploration, and career planning), the experimental group turned out to lack career development compared to the control group. The experimental group that applied for the program understood the intent and purpose of Gyeonggi Dream School (to provide career development through various program activities) and perceived their lack of career development, and thus applied for the program to have an opportunity of career exploration.

\section{Effects of the STEAMS-based gardening program on promoting career development}

Before the STEAMS-based gardening program, we compared the career development between the experimental group that applied for participation in gardening activities and the control group that did not apply for the program. The results showed that the experimental group had lower career development scores than the control group $(p<.001$; Table 4). Career development is categorized into self-aware- 
ness to understand oneself, education and occupational exploration to understand the occupation and required studies to achieve the dream, and career planning to prepare and plan the process required for the desired career. The experimental group showed a lower score than the control group in self-awareness $(p=.085)$, and the experimental group showed a significantly lower score than the control group in education and occupational exploration $(p<.001)$ and career planning $(p=.002)$. This implies that students in the experimental group that applied for the program lacked career development overall in all categories of self-awareness, education and occupational exploration, and career planning. However, after the program, the control group's scores in career development did not change, whereas the scores of the experimental group that participated in the program significantly increased in all of self-awareness, education and occupational exploration, and career planning. There was no score difference between the two groups after the program. This showed that all three categories used in the career development test of upper elementary students helped their development through the program.

\section{Change in the categories of career development before and after the gardening program}

\section{Change in self-awareness}

Among the categories of the career development test, self-awareness determines how well participants understand themselves, and is classified into awareness of selfconcept, awareness of self-trait, and awareness of human relations.

Awareness of self-concept determines the awareness to which one thinks positively about oneself, awareness of self-trait determines the understanding of one's strengths and characteristics, and awareness of human relations determines the awareness of positive and effective interaction with others, all of which rate how well one understands oneself (Lee, 2005).

In this study, self-awareness showed a lower score in the experimental group than the control group before the program $(p=.085)$, but while the score did not change in the control group after the program, the score increased in the experimental group $(p=.002)$, thereby eliminating the gap in self-awareness between the two groups (Table 5). This indicated that, while the students who applied for the program lacked understanding about themselves compared to the control group before the program, they could

Table 5. Pre-GAP and Post-GAP differences in self-awareness between the control and the treatment groups

\begin{tabular}{|c|c|c|c|c|c|}
\hline \multirow{2}{*}{ Category } & \multirow{2}{*}{ Group } & \multicolumn{2}{|c|}{ Mean (SD) } & \multirow{2}{*}{$t$} & \multirow{2}{*}{$p$} \\
\hline & & Pre-GAP & Post-GAP & & \\
\hline \multirow{3}{*}{ Awareness of self-concept } & Control & $11.73(2.57)$ & $11.93(2.34)$ & -0.44 & $.662^{\mathrm{NS}}$ \\
\hline & Experimental & $10.36(2.58)$ & $11.50(2.20)$ & -2.45 & $.021^{*}$ \\
\hline & $p$ & $.047^{\dagger}$ & $.472^{\mathrm{NS}}$ & & \\
\hline \multirow{3}{*}{ Awareness of self-trait } & Control & $17.13(2.92)$ & $16.17(4.36)$ & 1.40 & $.171^{\mathrm{NS}}$ \\
\hline & Experimental & $16.43(3.10)$ & $17.61(2.69)$ & -2.27 & $.031^{*}$ \\
\hline & $p$ & $.377^{\mathrm{NS}}$ & $.139^{\mathrm{NS}}$ & & \\
\hline \multirow{3}{*}{ Awareness of human relations } & Control & $12.97(2.09)$ & $13.00(1.89)$ & -0.13 & $.891^{\mathrm{NS}}$ \\
\hline & Experimental & $12.36(2.62)$ & $13.32(1.94)$ & -3.10 & $.004^{* *}$ \\
\hline & $p$ & $.331^{\mathrm{NS}}$ & $.526^{\mathrm{NS}}$ & & \\
\hline \multirow{3}{*}{ Total } & Control & $41.83(4.89)$ & $41.10(6.69)$ & 0.90 & $.372^{\mathrm{NS}}$ \\
\hline & Experimental & $39.14(6.72)$ & $42.43(5.46)$ & -3.51 & $.002^{* *}$ \\
\hline & $p$ & $.085^{\mathrm{NS}}$ & $.413^{\mathrm{NS}}$ & & \\
\hline
\end{tabular}

Note. GAP = gardening activity program.

${ }^{\mathrm{NS}}$ Non-significant, ${ }^{*} p<.05,{ }^{* *} p<.01$ by paired t-test.

${ }^{\mathrm{NS}}$ Non-significant, ${ }^{\dagger} p<.05$ by independent t-test. 
better understand themselves after the program.

Among the sub-categories of self-awareness, awareness of self-concept showed a lower score in the experimental group than the control group before the program $(p=.047)$, indicating that the participants had low positive awareness about themselves, but while the score did not change in the control group after the program, the score increased in the experimental group $(p=.021)$, thereby showing no difference between the two groups. This indicated that the program has a positive effect on students who lack positive awareness about themselves so that they see themselves more positively.

Unlike awareness of self-concept, awareness of self-trait and awareness of human relations did not show a significant difference between the two groups before and after the program. However, while the score did not change in the control group after the program, the awareness of self-trait and awareness of human relations scores increased in the experimental group that participated in gardening activities ( $p=.031$ and $p=.004$, respectively). This indicated that the experimental group can better understand their strengths and characteristics through the program, and also promoted positive human relations with others.

In previous studies, Relf (1998) argued that the gardening process encourages participants to share their experience with a common interest and respect one another more, thereby improving sociality, and Yoon (2001) claimed that flower and vegetable growing activities have positive effects on forming self-concept of elementary school students. Moreover, Kwack et al. (2015) proved that horticultural activities of elementary school students helped them better adapt to school life, feel confident, and build amicable social relations with friends, thereby improving self-esteem. The results of this study also showed that the sub-categories of self-awareness all improved in the experimental group after the STEAMS-based gardening program, which indicated that the program has positive effects on improving self-awareness of upper elementary students.

\section{Change in education and occupational exploration}

Among the categories of the career development test, education and occupational exploration is categorized into awareness of relationship between career and learning, awareness of relationship among work, personal responsibility and society function, and understanding and use of the career information. This category rates the ability to perceive various occupations and explore and collect career-related information. Awareness of relationship between career and learning measures the degree to which one perceives the need for learning in choosing a desired career. Awareness of relationship among work, personal responsibility and society function measures the understanding of various occupations, and understanding and use of the career information measures the ability to explore and collect information about the career one wants (Lee, 2005).

In this study, education and occupational exploration showed a significantly lower score in the experimental group than the control group before the program $(p<.001)$, but while the score did not change in the control group after the program, the score increased in the experimental group $(p<.001)$, thereby showing no difference between the two groups (Table 6). We also compared the results of sub-categories of education and occupational exploration such as awareness of relationship between career and learning, awareness of relationship among work, personal responsibility and society function, and understanding and use of the career information. It was found that the score increased in the experimental group that participated in gardening activities after the program $(p<.001)$, thereby showing no difference between the two groups. This indicated that, while the students in the experimental group who applied for the program lacked education and occupational exploration compared to the control group before the program, they could better explore career-related information after the program.

Among the sub-categories of education and occupational exploration, awareness of relationship between career and learning, awareness of relationship among work, personal responsibility and society function, and understanding and use of the career information all showed lower scores in the experimental group than the control group before the program ( $p=.006, p=.02$, and $p=.003$, respectively), indicating that the participants lacked education and occupational exploration overall. However, while there was no score change in the control group after the program, the 
Table 6. Pre-GAP and Post-GAP differences in education and occupational exploration between the control and the experimental groups

\begin{tabular}{|c|c|c|c|c|c|}
\hline \multirow{2}{*}{ Category } & \multirow{2}{*}{ Group } & \multicolumn{2}{|c|}{ Mean (SD) } & \multirow{2}{*}{$t$} & \multirow{2}{*}{$p$} \\
\hline & & Pre-GAP & Post-GAP & & \\
\hline \multirow{3}{*}{$\begin{array}{l}\text { Awareness of the relationship between } \\
\text { career and learning }\end{array}$} & Control & 7.57 (1.90) & $7.80(1.49)$ & -0.86 & $.394^{\mathrm{NS}}$ \\
\hline & Experimental & $5.93(2.40)$ & $7.86(1.90)$ & -3.82 & $<.001^{* * *}$ \\
\hline & $p$ & $.006^{\dagger \dagger}$ & $.899^{\mathrm{NS}}$ & & \\
\hline \multirow{3}{*}{$\begin{array}{l}\text { Awareness of the relationship among } \\
\text { work, personal responsibility and } \\
\text { society function }\end{array}$} & Control & $12.20(1.88)$ & $12.40(1.52)$ & -0.59 & $.557^{\mathrm{NS}}$ \\
\hline & Experimental & $11.07(1.67)$ & $12.89(1.91)$ & -5.05 & $<.001^{* * *}$ \\
\hline & $p$ & $.020^{\dagger}$ & $.280^{\mathrm{NS}}$ & & \\
\hline \multirow{3}{*}{$\begin{array}{l}\text { Understanding and use of the career } \\
\text { information }\end{array}$} & Control & $26.80(6.82)$ & $27.87(6.69)$ & -1.28 & $.208^{\mathrm{NS}}$ \\
\hline & Experimental & $21.79(5.46)$ & $27.04(5.66)$ & -6.02 & $<.001^{* * *}$ \\
\hline & $p$ & $.003^{\dagger}$ & $.613^{\mathrm{NS}}$ & & \\
\hline \multirow{3}{*}{ Total } & Control & $46.57(8.68)$ & $48.07(7.18)$ & -1.23 & $.225^{\mathrm{NS}}$ \\
\hline & Experimental & $38.79(6.59)$ & $47.79(6.74)$ & -7.68 & $<.001^{* * *}$ \\
\hline & $p$ & $<.001^{\dagger \dagger}$ & $.879^{\mathrm{NS}}$ & & \\
\hline
\end{tabular}

Note. GAP $=$ gardening activity program.

${ }^{\mathrm{NS}}$ Non-significant, ${ }^{* * *} p<.001$ by paired t-test.

${ }^{\mathrm{NS}}$ Non-significant, ${ }^{\dagger} p<.05,{ }^{\dagger} p<.01,{ }^{\dagger \dagger} p<.001$ by independent t-test.

scores of all sub-categories increased significantly in the experimental group that participated in the program $(p<$ $.001)$. This indicated that, in order for students in the experimental group that lack career-related studies to have the desired occupation through the program, they must perceive what kind of education they need, understand various occupations, and improve the ability to explore and collect career-related information; and the program had positive effects on doing that.

As such, the results of this study also proved that all sub-categories of education and occupational exploration in career development of students in the experimental group improved after the STEAMS-based gardening program, which indicated that the program had positive effects on improving education and occupational exploration of upper elementary students.

\section{Change in career planning}

Among the categories of the career development test, career planning determines the extent to which one makes preparations and plans for the desired occupation, and is categorized into understanding the decision making process, understanding the interrelationship of life roles, and understanding career planning process. Among the sub-cat- egories of career planning, understanding the decision making process determines the extent to which one understands the rational decision making process. Understanding the interrelationship of life roles measures the extent to which one understands work-life balance, and understanding career planning process determines the extent to which one understands the process of planning and preparing for his or her career, through which we can measure how much the program affects career development (Lee, 2005).

Like self-awareness and education and occupational exploration, this category also showed an increase of scores in the experimental group that participated in gardening activities $(p<.001$; Table 7). Career planning scores were lower in the experimental group than the control group before the program, but while the score did not change in the control group after the program, the score increased in the experimental group $(p<.001)$, thereby showing no difference between the two groups.

This indicates that the experimental group that applied for the program lacked career planning compared to the control group before the program, but after participating in the program, there was a positive effect from the opportunity to make plans about their careers through gardening activities. 
Table 7. Pre-GAP and Post-GAP differences in career planning between the control and the experimental groups

\begin{tabular}{|c|c|c|c|c|c|}
\hline \multirow{2}{*}{ Category } & \multirow{2}{*}{ Group } & \multicolumn{2}{|c|}{ Mean (SD) } & \multirow{2}{*}{$t$} & \multirow{2}{*}{$p$} \\
\hline & & Pre-GAP & Post-GAP & & \\
\hline \multirow{3}{*}{$\begin{array}{l}\text { Understanding the } \\
\text { decision-making process }\end{array}$} & Control & $10.77(2.41)$ & $11.23(2.16)$ & -1.07 & $.293^{\mathrm{NS}}$ \\
\hline & Experimental & $8.14(2.66)$ & $10.29(2.15)$ & -6.03 & $<.001^{* * *}$ \\
\hline & $p$ & $<.001^{\dagger \dagger}$ & $.100^{\mathrm{NS}}$ & & \\
\hline \multirow{3}{*}{$\begin{array}{l}\text { Understanding the } \\
\text { interrelationship of life } \\
\text { roles }\end{array}$} & Control & $19.00(4.89)$ & $18.37(4.95)$ & 1.46 & $.154^{\mathrm{NS}}$ \\
\hline & Experimental & $16.57(4.56)$ & $18.64(4.08)$ & -3.40 & $.002^{* *}$ \\
\hline & $p$ & $.056^{\mathrm{NS}}$ & $.818^{\mathrm{NS}}$ & & \\
\hline \multirow{3}{*}{$\begin{array}{l}\text { Understanding career } \\
\text { planning process }\end{array}$} & Control & $36.13(8.83)$ & $36.63(8.24)$ & -0.60 & $.552^{\mathrm{NS}}$ \\
\hline & Experimental & $29.93(8.08)$ & $36.79(6.18)$ & -5.47 & $<.001^{* * *}$ \\
\hline & $p$ & $.007^{\dagger \dagger}$ & $.937^{\mathrm{NS}}$ & & \\
\hline \multirow{3}{*}{ Total } & Control & $65.90(14.10)$ & $66.23(12.78)$ & -0.29 & $.774^{\mathrm{NS}}$ \\
\hline & Experimental & $54.64(11.83)$ & $65.71(10.51)$ & -7.36 & $<.001^{* * *}$ \\
\hline & $p$ & $.002^{\dagger \dagger}$ & $.867^{\mathrm{NS}}$ & & \\
\hline
\end{tabular}

Note. GAP = gardening activity program.

${ }^{\mathrm{NS}}$ Non-significant, ${ }^{* *} p<.01,{ }^{* * *} p<.001$ by paired t-test.

${ }^{\mathrm{NS}}$ Non-significant, ${ }^{\dagger} p<.01,{ }^{\dagger \top} p<.001$ by independent t-test.

We also compared the results of sub-categories of career planning. It was found that the scores of understanding the decision-making process, understanding the interrelationship of life roles, and understanding career planning process increased in the experimental group that participated in gardening activities after the program $(p<.001, p=.002$, and $p<.001$, respectively).

Understanding the decision-making process showed a significantly lower score in the experimental group than the control group before the program $(p<.001)$, indicating that the experimental group lacked understanding of the decision-making process. However, while there was no score change in the control group after the program $(p=.293)$, the score increased significantly in the experimental group that participated in the program $(p<.001)$, thereby showing no difference between the two groups after the program $(p=.100)$. This result proves that the program has positive effects on one's understanding of the rational decision making process and attitudes in choosing one's career.

Understanding the interrelationship of life roles did not show a difference between the two groups both before $(p=.056)$ and after the program $(p=.818)$. However, while there was no score change in the control group after the program, the score increased significantly in the ex- perimental group that participated in the program $(p=.002)$, indicating that the program has positive effects on perceiving the importance of work-life balance and planning the career.

Understanding career planning process showed a lower score in the experimental group than the control group before the program $(p=.007)$, indicating that the experimental group lacked understanding of career planning process, but while there was no score change in the control group after the program, the score increased significantly in the experimental group that participated in the program $(p<$ $.001)$. This result proves that the program has positive effects on setting one's career direction and making preparations and plans for the future career.

Lee (2011) reported that career education using plant cultivation helped set the career direction for elementary school students, and Kim (2007) stated that plant education programs have a positive effect on making career decisions. The results of this study also showed a significant increase in the scores of all sub-categories of career planning in the experimental group that participated in gardening activities after the STEAMS-based gardening program, which indicated that the program has positive effects on improving career planning of upper elementary students. 


\section{Conclusion}

The results of this study showed that the STEAMS-based gardening program used in this study has positive effects on career development of upper elementary students that participated in gardening activities, showing improvement in all sub-categories of career development such as self-awareness, education and occupational exploration, and career planning. The results contributed to laying the foundation for career interest and development by introducing the history of garden-related occupations, activity areas, job competencies and career process required for the occupations, and carrying out related gardening activities.

However, the participants were limited to only the upper elementary students that applied for participation in 'Gyeonggi Dream School-Eco Garden Design' and the results were obtained by applying the program to 28 students in the experimental group. Therefore, a follow-up study is needed to revalidate the effects of the program and increase validity by increasing the population.

\section{References}

Cameron, R. 2016, July. Gardening: Value in terms of human health and well-being. Speaker session at the Ornamental Roundtable Health and Horticulture Conference 2016. Hampton Court Palace, England: The University of Sheffield and the Royal Horticultural Society.

Gyeonggido Office of Education. 2014. Gyeonggi Dream School. Retrieved from https://www.goe.go.kr

Gyeonggido Office of Education. 2015. Announcement for 2015 Gyeonggi Dream School project development. Retrieved from https://www.goe.go.kr

Hartung, P.J., E.J. Porfeli, and F.W. Vondracek. 2005. Child vocational development: A review and reconsideration. J. Vocat. Behav. 66(3):385-419. https://doi.org/10.1016/ j.jvb.2004.05.006

Jeung, E.J., Y.K. Jeung, N.R. Kim, J.Y. Ryu, J.H. Kim, and H.J. Jang. 2018. Status of career development. A study on current status of primary and secondary school career education in 2018. Sejong, Korea: Korea Research Institute for Vocational Education and Training.
Retrieved from http://www.krivet.re.kr

Jeong, S.J., G.M. Gim, J.S. Kim, Y.A. Jang, K.S. Han, S.M. Lee, H.S. Jang, J.W. Park, and S.H. Ma. 2017. 'From seed to flower cafe' career experience program associated with direct experience and indirect experience for middle school students. Jeollabuk-do, Korea: National Institute of Horticultural and Herbal Science, Rural Development Administration.

Jyung, C.Y., B.W. Kim, B.K. Song, D.S. Choi, J.B. Lee, E.S. Kim, H.S. Joo, and B.K. Kim. 2012. The effect of vocation experience activity on elementary school students' career development, academic motive, creativity and sociality. J. Career Educ. Res. 25(3):1-17.

Kim, J.H. 2007. Effect of plants education on the career attitude maturity to elementary school students. J. Korean Pract. Arts Educ. 20(3):251-262.

Korea Foundation for the Advancement of Science and Creativity. 2011. STEAM education. Retrieved from https://steam.kofac.re.kr

Kwack, H.R., K.W. Han, and J.S. Choi. 2015. Effect of educational gardening for multicultural understanding on elementary school student self-esteem, care, multicultural understanding and attitude. J. Korean Soc. People Plants Environ. 18(1):1-11. https://doi.org/10.11628/ksppe.201 5.18.1.001

Lee, J.B. 2005. The development and validation of a career development inventory for elementary school students. Doctoral dissertation, Seoul National University, Seoul, Korea.

Lee, K.S. 2011. The effect of career education program using life science on career maturity for elementary school students. Master's thesis, Seoul National University of Education, Seoul, Korea.

Lee, S.G. and N.Y. Chung. 2014. The effects of the career education program for the creative experience activities on the children's career development. J. Korean Pract. Arts Educ. 27(1):105-115.

Ministry of Education. 2010. STEAM guide. Sejong. Korea: Author. Retrieved from https://www.moe.go.kr

Passy, R., M. Morris, and F. Reed. 2010. Impact of school gardening on learning. Final report submitted to the Royal Horticultural Society. Retrieved from https://www.nfer. ac.uk/media/2135/rhs01.pdf 
Relf, P.D. 1998. The role of horticulture in human well-being and quality of life. J. Korean Soc. People Plants Environ. 1(1):12-21.

Royal Horticultural Society. 2010. Growing together: Gardening with children and young people with special educational needs. RHS SEN Schools Project 2009-2010. London, UK: Author.

Royal Horticultural Society. 2018. RHS campaign for school gardening. Retrieved from https://schoolgardening.rhs.o rg.uk/home

Schwab, K. 2016. The fourth industrial revolution [forum]. World Economic Forum. Retrieved from https://www.w eforum.org

Seo, W.S. and K.S. Do. 2002, November. Logic and reality of primary school career educ. Proceedings of the Korean Society for the Study of Career Education 2002 Fall Conference (pp. 1-33).

Super, D.E., M.L. Savickas, and C.M. Super. 1996. The life span, life space approach to careers. In: D. Brown \& L. Brooks (Eds.), Career choice and development (3rd ed., pp. 121-178). San Francisco, CA: Jossey-Bass.

Yoon, S.K. 2001. The effect of the plant-culture working on changes in children's personality. Master's thesis, Seoul National University of Education, Seoul, Korea. 